\title{
Utilization of Pharmacological Ascorbate to Enhance Hydrogen Peroxide-Mediated Radiosensitivity in Cancer Therapy
}

\author{
Zain Mehdi, Michael S. Petronek, Jeffrey M. Stolwijk (D), Kranti A. Mapuskar ${ }^{(D)}$, Amanda L. Kalen,

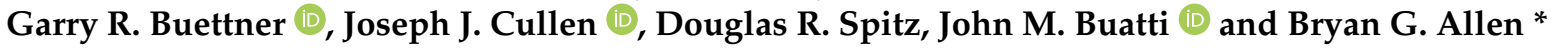 \\ Free Radical and Radiation Biology Program, Department of Radiation Oncology, The University of Iowa, \\ Iowa City, IA 52242, USA; zain-mehdi@uiowa.edu (Z.M.); michael-petronek@uiowa.edu (M.S.P.); \\ jeffrey-stolwijk@uiowa.edu (J.M.S.); krantiashok-mapuskar@uiowa.edu (K.A.M.); \\ amanda-kalen@uiowa.edu (A.L.K.); garry-buettner@uiowa.edu (G.R.B.); joseph-cullen@uiowa.edu (J.J.C.); \\ douglas-spitz@uiowa.edu (D.R.S.); john-buatti@uiowa.edu (J.M.B.) \\ * Correspondence: bryan-allen@uiowa.edu; Tel.: +1-319-356-7601
}

\section{check for} updates

Citation: Mehdi, Z.; Petronek, M.S.; Stolwijk, J.M.; Mapuskar, K.A.; Kalen, A.L.; Buettner, G.R.; Cullen, J.J.; Spitz, D.R.; Buatti, J.M.; Allen, B.G.

Utilization of Pharmacological Ascorbate to Enhance Hydrogen Peroxide-Mediated Radiosensitivity in Cancer Therapy. Int. J. Mol. Sci. 2021, 22, 10880. https://doi.org/ 10.3390/ijms221910880

Academic Editor: Janusz Adam Rak

Received: 2 September 2021

Accepted: 4 October 2021

Published: 8 October 2021

Publisher's Note: MDPI stays neutral with regard to jurisdictional claims in published maps and institutional affiliations.

Copyright: (c) 2021 by the authors. Licensee MDPI, Basel, Switzerland. This article is an open access article distributed under the terms and conditions of the Creative Commons Attribution (CC BY) license (https:// creativecommons.org/licenses/by/ $4.0 /)$.

\begin{abstract}
Interest in the use of pharmacological ascorbate as a treatment for cancer has increased considerably since it was introduced by Cameron and Pauling in the 1970s. Recently, pharmacological ascorbate has been used in preclinical and early-phase clinical trials as a selective radiation sensitizer in cancer. The results of these studies are promising. This review summarizes data on pharmacological ascorbate (1) as a safe and efficacious adjuvant to cancer therapy; (2) as a selective radiosensitizer of cancer via a mechanism involving hydrogen peroxide; and (3) as a radioprotector in normal tissues. Additionally, we present new data demonstrating the ability of pharmacological ascorbate to enhance radiation-induced DNA damage in glioblastoma cells, facilitating cancer cell death. We propose that pharmacological ascorbate may be a general radiosensitizer in cancer therapy and simultaneously a radioprotector of normal tissue.
\end{abstract}

Keywords: pharmacological ascorbate; radiation therapy; reactive oxygen species; hydrogen peroxide; radiosensitization

\section{Introduction}

Of the approximately 1,800,000 new cases of cancer diagnosed in the United States each year, half will receive some form of ionizing radiation therapy (RT) as part of their therapy [1]. RT may be used alone or in combination with surgery and chemotherapy as treatment for various types of cancer. DNA damage induced by RT is central to its function in treating cancer. Ionizing radiation induces both DNA single- and double-strand breaks (SSB and DSB) that can lead to cell death due to increased genomic instability in cancer cells [2]. Additionally, RT can affect homeostasis and the redox environment of cells [3]. Since RT alone is often insufficient to provide tumor control for many cancer types, combinations with different chemotherapies have become ubiquitous, especially in the treatment of certain aggressive cancers [4,5]. Several cancer types that do not respond well to radiation and/or chemotherapy regimens have accelerated the development of additional radiation sensitizers.

In the 1970s, Cameron and Pauling introduced pharmacological ascorbate ( $\left.\mathrm{P}-\mathrm{AscH}^{-}\right)$ as a potential cancer therapy. $\mathrm{P}-\mathrm{AscH}^{-}$is $\mathrm{IV}$-administered in gram doses $(\approx 5 \mathrm{~g}$ to $100 \mathrm{~g}$ or more), yielding millimolar concentrations in blood. $\mathrm{P}-\mathrm{AscH}^{-}$is to be viewed as a drug; actually, it is a pro-drug for hydrogen peroxide [6]. Since the introduction of $\mathrm{P}-\mathrm{AscH}^{-}$into the cancer-arena, considerable research has been published highlighting its role not only as a cancer drug but also as a potential radiosensitizer. This research has produced promising results for some of the most aggressive cancer types including glioblastoma (GBM), non-small cell lung cancer (NSCLC), and pancreatic cancer [4,5,7]. Historically, these ag- 
gressive cancers respond poorly to radiation and chemoradiation treatment approaches, accentuating the need to explore alternative and adjuvant therapies like $\mathrm{P}-\mathrm{AscH}^{-}$.

GBM is the most common primary brain cancer in the U.S.A. accounting for $70 \%$ of the 22,500 new malignant primary brain tumors diagnosed each year [8]. The current treatment regimen of surgical resection, RT, and chemotherapy with temozolomide (TMZ) is exceedingly aggressive, with up to $54 \%$ of patients experiencing seizures 5 days postoperatively. The median survival remains less than two years [9-12].

A more common and difficult-to-treat cancer type is lung cancer. It is the leading cause of cancer-related death in the U.S.A., with approximately 200,000 new cases and nearly 200,000 deaths each year [13]. Non-small cell lung cancer (NSCLC) accounts for $80 \%$ of lung cancer cases. It is treated in a variety of ways including RT, chemotherapy, targeted therapy, immunotherapy, and combination treatments. Despite treatment algorithms, the five-year survival for NSCLC remains only 15\% [14].

Additionally, pancreatic cancer is the fourth deadliest cancer, with more than 48,000 deaths in the U.S.A. [15]. Five-year survival is only $10.8 \%$. A major consideration in pancreatic cancer is local disease, as $30 \%$ of patients succumb to local disease progression. Thus, improving current RT regimens to combat local disease is an important avenue in treating these patients [16].

These cancers are examples of some of the most difficult to treat, with very poor five-year prognoses. However, there are encouraging data on the potential of $\mathrm{P}-\mathrm{AscH}^{-}$ as an adjuvant to radiation and chemotherapy therapy. This review presents the current state of knowledge on $\mathrm{P}_{-} \mathrm{AscH}^{-}$as an adjuvant to standard-of-care therapies, where it acts as a radiosensitizer via $\mathrm{H}_{2} \mathrm{O}_{2}$-mediated cytotoxicity in cancer cells and tissue and as a radioprotector of normal cells and tissues.

\section{History of the Use of $\mathbf{P - A s c H}{ }^{-}$as a Cancer Drug}

P-AscH ${ }^{-}$was first assessed as a potential cancer treatment in the 1970s by Cameron and Pauling, who hypothesized that $\mathrm{P}-\mathrm{AscH}^{-}$improved host resistance to metastatic cancer growth $[7,17]$. At the time, the theory supporting the use of ascorbate was that terminal cancer patients presented with scurvy-like symptoms due to low ascorbate levels. Therefore, the administration of ascorbate could lead to potential benefits [7]. The two researchers conducted clinical trials comparing overall survival between advanced cancer patients treated solely with $\mathrm{P}-\mathrm{AscH}^{-}$and untreated matched historical controls $[18,19]$. These trials demonstrated the safety of intravenous (IV) $\mathrm{P}_{-} \mathrm{AscH}^{-}$and its potential efficacy as a cancer therapy. Specifically, 100 terminal cancer patients were given $10 \mathrm{~g}$ of IV P$\mathrm{AscH}^{-}$for 10 days, followed by $10 \mathrm{~g}$ of oral supplementation and were matched with 1000 historical control patients. While there was some variability depending on the cancer type, the data showed a four-fold increase in the survival of patients treated with $\mathrm{P}-\mathrm{AscH}^{-}$ compared to matched controls [20,21].

In a randomized, double-blinded clinical trial involving 123 advanced cancer patients with tumors in various primary sites, oral ascorbate showed no therapeutic advantage when compared to placebo (60 patients receiving a placebo, and 63 administered oral P-AscH ${ }^{-}, 10 \mathrm{~g}$ ) [22]. This study was repeated in colorectal carcinoma patients with similar negative results [23]. Because these trials failed to support Cameron and Pauling's original results, interest in ascorbate as a potential treatment option for cancer patients waned.

Lack of interest in $\mathrm{P}-\mathrm{AscH}^{-}$as a cancer therapy continued until the late 1990s and early 2000s. During this time, comparative pharmacokinetic analysis between oral and IV administration of $\mathrm{P}-\mathrm{AscH}^{-}$uncovered that significantly greater concentrations of $\mathrm{AscH}^{-}$in blood could be achieved via IV administration, safely reaching concentrations of $25-30 \mathrm{mM}$, compared to the oral route that allows a maximal concentration of approximately $220 \mu \mathrm{M}$ [24-27]. With this discovery, interest in high-dose, IV-administered $\mathrm{P}-\mathrm{AscH}^{-}$reemerged as a potential therapeutic avenue for cancer treatment.

Since then, various preclinical and clinical trials have explored the therapeutic benefit and mechanism of $\mathrm{P}-\mathrm{AscH}^{-}$as a cancer treatment, either alone or in combination 
with standard-of-care radiation and/or chemotherapy treatments. Through explorative mechanistic studies, hypotheses were developed that $\mathrm{P}-\mathrm{AscH}^{-}$functions in cancer therapy via reactive oxygen species (ROS) and oxidative damage to cancer cells. While various contentions were made to this potential mechanism, only recently has significant progress been made demonstrating the importance of oxidative damage via $\mathrm{P}-\mathrm{AscH}^{-}$administration. Nonetheless, clinical trials prior to this exploration demonstrated the efficacy of this therapy.

In 2004, a small study in seven patients with renal cell carcinoma, pancreatic cancer, colorectal cancer, non-Hodgkin's lymphoma, or breast cancer demonstrated the safety of $\mathrm{P}-\mathrm{AscH}^{-}$[28]. In the two renal cell carcinoma case-study patients, $\mathrm{P}_{-} \mathrm{AscH}^{-}$alone resulted in the resolution of disease. In a late-stage colorectal carcinoma patient, a combination of chemotherapy (5-FU and leucovorin) followed by $\mathrm{P}-\mathrm{AscH}^{-}$(plasma ascorbate concentration of $20 \mathrm{mM}$ ) resulted in resolution of the disease with minimal side effects associated with $\mathrm{P}-\mathrm{AscH}^{-}$. In a pancreatic cancer patient that was refractory to gemcitabine, treatment with $\mathrm{P}-\mathrm{AscH}^{-}$combined with gemcitabine decreased CA-19-9 and slowed tumor growth. In a non-Hodgkin's lymphoma patient who refused chemotherapy or radiation, $\mathrm{P}-\mathrm{AscH}^{-}$alone (15 $\mathrm{g}$ infusions) resulted in complete resolution of the disease. Another nonHodgkin's lymphoma patient who discontinued chemotherapy because of associated side effects was administered $\mathrm{P}-\mathrm{AscH}^{-}$and showed no evidence of disease within three months of treatment, with complete remission by the end of 11 months of treatment. In addition, an end-stage, metastatic breast carcinoma patient treated with daily $\mathrm{P}-\mathrm{AscH}^{-}$(maximum dosage of $100 \mathrm{~g} / \mathrm{d}$ ) reported a significant reduction in bone metastases and a marked improvement in quality of life within three months from the start of treatment. The encouraging results described in these selected case reports generated renewed investigation of $\mathrm{P}-\mathrm{AscH}^{-}$for use in cancer treatment.

In the 2010s, early-phase clinical trials showed potential efficacy of combining P$\mathrm{AscH}^{-}$with chemotherapy and radiation. Phase I trials in metastatic pancreas cancer combining P-AscH ${ }^{-}$with erlotinib and gemcitabine or gemcitabine alone found the combinations to be safe, with toxicity similar to chemotherapy alone and potential promising clinical outcomes $[29,30]$.

Furthermore, in an important development for pancreatic cancer therapy, we worked with colleagues at our institution to conduct a phase I clinical trial involving 14 locally advanced pancreatic cancer patients treated with gemcitabine, radiation, and $\mathrm{P}-\mathrm{AscH}^{-}$, who demonstrated an overall survival (OS) of 21.7 months (an increase from an institutional average of 12.7 months) and progression-free survival (PFS) of 13.7 months (an increase from 4.6 months) [15]. In addition, three patients were disease-free 5 years after treatment. Beyond a potential therapeutic gain, this study also provided evidence that $\mathrm{P}-\mathrm{AscH}^{-}$ decreased radiation-induced bowel injury in pre-clinical animal models.

In addition to pancreatic cancer, a phase I clinical trial of 11 glioblastoma patients who were treated with standard-of-care treatments (temozolomide and RT) plus P-AscH ${ }^{-}$ showed a higher OS of 18 months and a higher PFS of 9.4 months compared to historical medians of 14.6 months and 7 months, respectively [31]. Moreover, these data also included eight GBM patients with an unmethylated O-6-methylguanine-DNA methyltransferase (MGMT) promoter, which generally have worse prognoses, with a historic median OS of 12 months. The median OS in the trial for these patients was 23 months, and the median PFS was 10 months [31,32]. Although the investigation of efficacy is not a goal of phase I trials, these observations are very encouraging.

Due to the tumor- and therapy-specific variability in the apparent efficacy of $\mathrm{P}-\mathrm{AscH}^{-}$, there is a need for continued preclinical and clinical research exploring the underlying mechanism of $\mathrm{P}-\mathrm{AscH}^{-}$-mediated cytotoxicity. Nonetheless, these clinical trials are promising for the use of $\mathrm{P}_{-} \mathrm{AscH}^{-}$as an adjuvant to the standard of care. Exciting is that these early results support the concept that $\mathrm{P}-\mathrm{AscH}^{-}$may be useful as a radiosensitizer and that it may simultaneously serve as a radioprotector of vulnerable normal tissue. 


\section{Radiation-Induced Injury in Cancer and the Role of Hydrogen Peroxide}

The role of $\mathrm{P}-\mathrm{AscH}^{-}$as a radiosensitizer and its proposed mechanism of $\mathrm{H}_{2} \mathrm{O}_{2}-$ mediated cytotoxicity are based on the generation of reactive oxygen species (ROS) following RT. RT exerts its effects on DNA either by directly damaging DNA or by indirectly interacting with water molecules to form oxidizing free radicals that in turn lead to DNA damage [33]. Because low linear energy transfer (LET) radiation (i.e., photons) is the primary clinical RT modality and because water makes up $50-60 \%$ of the adult body weight, $\mathrm{RT}^{\prime}$ 's indirect mechanism of DNA damage dominates, wherein ionization of water generates oxidizing chemical species (i.e., ROS) that will damage target biomolecules, namely, proteins, lipids, and most significantly, DNA [34,35].

ROS can be divided into two broad groups: free radicals and non-radicals. Some free radicals are highly reactive species, including superoxide $\left(\mathrm{O}_{2}{ }^{--}\right)$, hydroxyl radical $\left(\mathrm{HO}^{\bullet}\right)$, nitric oxide $(\mathrm{NO})^{\bullet}$, peroxyl radicals $\left(\mathrm{ROO}^{\bullet}\right)$, alkoxyl radicals $\left(\mathrm{RO}^{\bullet}\right)$, etc., whereas, non-radical ROS species include hydrogen peroxide $\left(\mathrm{H}_{2} \mathrm{O}_{2}\right)$, singlet oxygen $\left({ }^{1} \mathrm{O}_{2}\right)$, organic hydroperoxides $(\mathrm{ROOH})$, peroxynitrite $\left(\mathrm{ONOO}^{-}\right)$, etc. [36]. Increased levels of ROS have been detected in almost all types of cancers and may play a critical role in mediating tumor development and progression [37-39]. Elevated ROS levels in cancer can be attributed to mitochondrial dysfunction, increased activity of NAPDH oxidases, increased expression of oncogenes, and overwhelmed or downregulated metabolic pathways that detoxify ROS [36,38,40-44]. The type, location, and concentration of the free radicals generated following RT can activate specific downstream pathways that can affect cellular functions in cancer cells [36].

ROS generated by RT are indiscriminate of cancerous and non-cancerous tissues. Thus, RT-induced ROS can accelerate tumor cell killing but also cause normal tissue injury via impairment of mitochondrial dysfunction and genomic instability [45]. There are several cancers treated with RT where RT-induced, dose-limiting complications occur in normal tissue that limit the therapeutic benefit of RT alone. Specifically, the lungs are one of the most sensitive tissues to RT; therefore, their increased susceptibility to RT damage limits treatment. Studies in lung and esophageal cancers have shown that RT effects on the lung can be seen as acute toxicity (hours to days following RT) and late injury (months to years following RT) including pulmonary fibrosis, necrosis, and atrophy [46]. During standard RT treatment for brain cancers such as fractionated partial- and whole-brain radiation treatment (PBRT and WBRT), healthy brain tissue is inevitably exposed, resulting in side effects, such as learning and cognitive deficits, including memory impairment, neurological deficits, increased intracranial pressure, and progressive dementia [47-50]. Therefore, the indiscriminate nature of RT-induced ROS and cellular damage underscores the necessity for developing therapies, such as $\mathrm{P}-\mathrm{AscH}^{-}$, to selectively enhance the effects of radiation on cancer cells, while simultaneously protecting normal tissues from RT-induced toxicity [51].

\section{4. $\mathrm{P}-\mathrm{AscH}^{-}$and the Flux of Hydrogen Peroxide}

While RT-induced ROS formation is a fundamental physiochemical mechanism in cancer cell killing, ROS generation is also central to the selective toxicity of $\mathrm{P}-\mathrm{AscH}^{-}$. As evidenced by early pharmacokinetic work, the anti-cancer effects of $\mathrm{P}_{-} \mathrm{AscH}^{-}$occur primarily at supraphysiological plasma concentrations [24]. Humans have evolved to tightly control the concentration of ascorbate following oral ingestion through the processes of intestinal absorption, ascorbate transport, and renal excretion [24,27]. Consuming $\geq 200 \mathrm{mg}$ of ascorbate decreases its intestinal absorption [52]. At a plasma concentration of $\approx 60 \mathrm{mM}$, the ascorbate transporter, sodium vitamin C transporter 2 (SVCT2), is saturated and approaches its $V_{\max }$, and renal absorption declines, with excess ascorbate being excreted in the urine $[24,27,53]$. Alternatively, intravenous administration of $\mathrm{P}-\mathrm{AscH}^{-}$bypasses these control mechanisms resulting in supraphysiologic plasma and tissue ascorbate concentrations $(\mathrm{mM})$ that selectively induce cancer cell death [54]. Intracellularly, concentrations of $\mathrm{H}_{2} \mathrm{O}_{2}$ between 0.001 and $10 \mu \mathrm{M}$ are involved in signal transduction pathways required for cell survival [54]. At these low intracellular concentrations, $\mathrm{H}_{2} \mathrm{O}_{2}$ can cause reversible 
oxidation of redox-sensitive transcription factors and enzymes [54]. However, $\mathrm{P}-\mathrm{AscH}^{-}$ has been shown to generate fluxes of $\mathrm{H}_{2} \mathrm{O}_{2}$ beyond the detoxification capacity of the cell, leading to cell death $[55,56]$.

The proposed mechanism of $\mathrm{P}-\mathrm{AscH}^{-}$-mediated cancer cell toxicity is via the redoxactive metal-mediated formation of $\mathrm{H}_{2} \mathrm{O}_{2}(\mathbf{R x n} \mathbf{1})[5,6,57]$.

$$
\mathrm{AscH}^{-}+\mathrm{O}_{2}+\mathrm{H}^{+} \text {aq } \rightarrow \mathrm{H}_{2} \mathrm{O}_{2}+\mathrm{DHA}
$$

where DHA is dehydroascorbic acid, the two-electron oxidation product of $\mathrm{AscH}^{-}$. Rxn 1 is the overall reaction with many steps in the mechanism, vide infra.

Pioneering work by Chen et al. in 2005 identified $\mathrm{P}_{-} \mathrm{AscH}^{-}$as a pro-drug for the generation of $\mathrm{H}_{2} \mathrm{O}_{2}$ in tissues [58]. In the presence of redox-active metals, ascorbate is oxidized forming the ascorbate radical $\left(\mathrm{Asc}^{\bullet-}\right)$ and a reduced metal $[58,59]$. The reduced metal then transfers an electron to molecular oxygen, forming superoxide $\left(\mathrm{O}_{2}{ }^{\bullet-}\right)$. Superoxide can be converted into $\mathrm{H}_{2} \mathrm{O}_{2}$ via superoxide dismutases. $\mathrm{H}_{2} \mathrm{O}_{2}$ formation is linearly related to $\mathrm{Asc}^{\bullet-}$ formation, with detectable $\mathrm{H}_{2} \mathrm{O}_{2}$ formation occurring when [Asc ${ }^{\bullet-}$ ] exceeds $100 \mathrm{nM}$ [6]. Because $\mathrm{H}_{2} \mathrm{O}_{2}$ is uncharged, it can passively diffuse across membranes; however, certain aquaporins, termed peroxiporins, actively import $\mathrm{H}_{2} \mathrm{O}_{2}$ into cells; they are the primary facilitators of cellular uptake of extracellular $\mathrm{H}_{2} \mathrm{O}_{2}$. This gating of import modulates the intracellular effects of extracellular $\mathrm{H}_{2} \mathrm{O}_{2}$, specifically, intracellular oxidative distress that can lead to cell death $[54,60]$. This hypothesized $\mathrm{H}_{2} \mathrm{O}_{2}$-dependent mechanism for the selectivity of $\mathrm{P}-\mathrm{AscH}^{-}$was confirmed with intracellular as well as extracellular catalase, an enzyme that removes $\mathrm{H}_{2} \mathrm{O}_{2}$ converting it to water and oxygen. The inclusion of catalase prior to treatment with $\mathrm{P}-\mathrm{AscH}^{-}$has been shown to mitigate $\mathrm{P}-\mathrm{AscH}^{-}$toxicity [6]. Conversely, the introduction of superoxide dismutase prior to treatment with $\mathrm{P}-\mathrm{AscH}^{-}$ enhanced intracellular $\mathrm{H}_{2} \mathrm{O}_{2}$ formation by $\mathrm{P}_{-} \mathrm{AscH}^{-}$[6]. Thus, $\mathrm{ROS}$ generation is critical for the toxicity of $\mathrm{P}-\mathrm{AscH}^{-}$.

With ROS generation being crucial for the mechanisms of action for both RT and $\mathrm{P}-\mathrm{AscH}^{-}$, several preclinical studies have explored the potential radio-sensitizing role of $\mathrm{P}-\mathrm{AscH}^{-}$. In vitro studies using NSCLC and GBM cells demonstrated that treatment with $40 \mathrm{pmol} \mathrm{cell}^{-1}(2 \mathrm{mM})$ of $\mathrm{P}_{-} \mathrm{AscH}^{-}$for $1 \mathrm{~h}$ in combination with chemoradiation ( $5 \mu \mathrm{M}$ of carboplatin or TMZ) for $1 \mathrm{~h}$ and 2 gray (Gy) ionizing radiation (IR) led to significant reduction in clonogenic cell survival compared to $\mathrm{P}-\mathrm{AscH}^{-}$or chemoradiation alone [5]. Conversely, no significant difference was observed in normal human bronchial epithelial cells (HBEpC) and normal human astrocytes (NHA) treated with $\mathrm{P}_{-} \mathrm{AscH}^{-}$and chemoradiation as compared to the chemoradiation group, suggesting that the combined treatment of $\mathrm{P}-\mathrm{AscH}^{-}$and chemoradiation was selectively toxic to cancer cells [5]. To support the notion that $\mathrm{P}-\mathrm{AscH}^{-}$exhibits a functional radiosensitizer role, treatment of pancreatic cancer cells with $\mathrm{P}-\mathrm{AscH}^{-}$showed that administration either an hour before or an hour after IR was more cytotoxic than when $\mathrm{P}-\mathrm{AscH}^{-}$was administered six hours after IR. These data suggest that the synergistic effects of $\mathrm{P}-\mathrm{AscH}^{-}$and IR may be due to enhanced propagation of ROS following IR [4]. Similar experiments have shown that $\mathrm{P}-\mathrm{AscH}^{-}$is selectively toxic to cancer cells and enhances radiation sensitivity in non-small cell lung cancer, glioblastoma, sarcoma, and pancreatic cancer, while remaining relatively innocuous to normal cells $[4,5,55,61]$.

These data, vide supra, indicate that $\mathrm{P}-\mathrm{AscH}^{-}$-induced fluxes of $\mathrm{H}_{2} \mathrm{O}_{2}$ are central to its ability to function as a radiosensitizer. Thus, we hypothesized that $\mathrm{P}-\mathrm{AscH} \mathrm{H}^{-}$would enhance IR-induced DNA damage. We tested if $\mathrm{P}-\mathrm{AscH}^{-}$can enhance IR-induced DNA damage via increase flux of $\mathrm{H}_{2} \mathrm{O}_{2}$ using doxycycline-inducible catalase-overexpressing U87 GBM cells (See Materials and Methods section for protocol details.). Catalase activity was eight times that of controls in the overexpressing cells, as shown in Figure 1A. Cells treated with $\mathrm{P}-\mathrm{AscH}^{-}$and IR individually revealed an increase in double-stranded DNA damage, as assessed by phosphorylated $\mathrm{H} 2 \mathrm{AX}(\gamma \mathrm{H} 2 \mathrm{AX})$, relative to sham-treated cells, as shown in Figure 1B. The combination of $\mathrm{P}-\mathrm{AscH}^{-}$and IR resulted in significantly more $\gamma \mathrm{H} 2 \mathrm{AX}$ than in untreated cells, as shown in Figure $1 \mathrm{~B}$. To investigate the role of $\mathrm{H}_{2} \mathrm{O}_{2}$, 
doxycycline inducible catalase-overexpressing $\mathrm{U} 87$ cells were treated with $\mathrm{P}-\mathrm{AscH}{ }^{-}, \mathrm{RT}$, and doxycycline; we observed no difference in $\gamma \mathrm{H} 2 \mathrm{AX}$ compared to the amount measured after treatment with IR alone, indicating that $\mathrm{H}_{2} \mathrm{O}_{2}$ may be critical for $\mathrm{P}-\mathrm{AscH}^{-}$to function as a radiosensitizer. These results warrant further investigation into the ability of $\mathrm{P}-\mathrm{AscH}^{-}$ to enhance IR-induced DNA damage with regards to both time and dose dependence.

A.

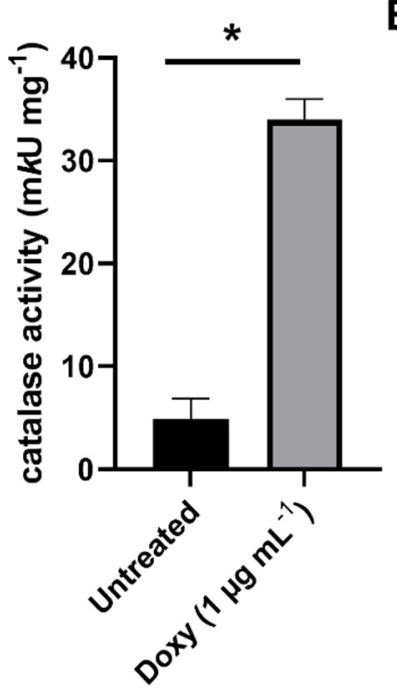

B.

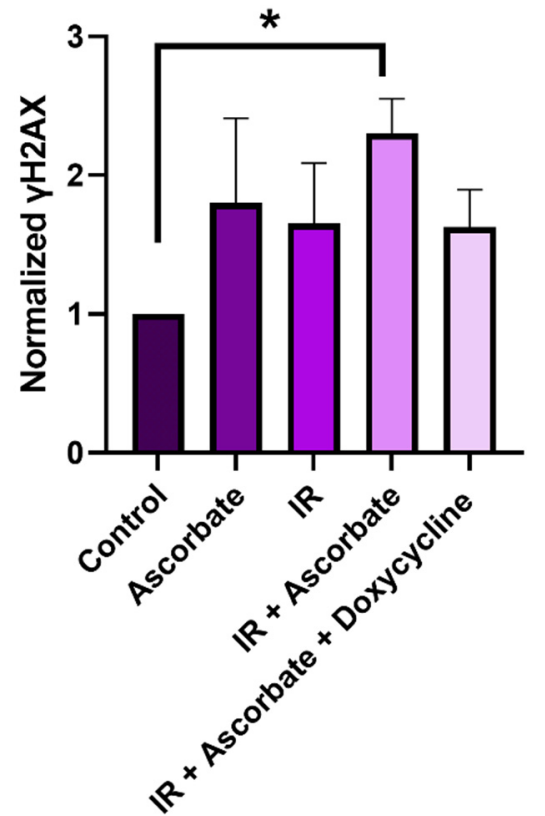

Figure 1. $\mathrm{P}-\mathrm{AscH}^{-}$enhances DNA damage induced by ionizing radiation (IR) in GBM cells, as seen by activation of $\gamma \mathrm{H} 2 \mathrm{AX}$. (A) Catalase activity is increased by $\approx 8$-fold in catalase-overexpressing U87 cells. ${ }^{*} p<0.05$. Doxy (doxycycline) initiates the cellular overexpression of catalase. (B) IR + ascorbate increases DNA damage, as seen by normalized $\gamma \mathrm{H} 2 \mathrm{AX}$ expression in U87 cells. Ascorbate concentrations were $10 \mathrm{pmol} /$ cell $(2 \mathrm{mM})$. The dose of IR was $4 \mathrm{~Gy}$. Doxycycline treatment was $1 \mu \mathrm{g} / \mathrm{mL}$. Unpaired Student's $t$-test was used to compare IR $+\mathrm{P}-\mathrm{AscH}^{-}$with control, ${ }^{*} p<0.05$.

One hypothesis to explain how high doses of ascorbate selectively kill cancer cells while having minimal effect on non-malignant cells proposes that cancer cells have increased uptake of dehydroascorbic acid (DHA), the two-electron oxidation product of ascorbate, via increased expression of GLUT1 transporters [62]. Increases in DHA in cancer cells could deplete cellular glutathione levels and thereby augment cancer cell oxidative distress [62]. However, later studies showed that competitive inhibition of GLUT transporters with 2-deoxy-D-glucose did not suppress $\mathrm{P}-\mathrm{AscH}^{-}$toxicity but rather enhanced $\mathrm{P}-\mathrm{AscH}^{-}$toxicity [5]. Thus, these data along with the kinetic arguments presented by Doskey et al. [56] rule out this mechanism as a significant contributor to the toxicity of $\mathrm{P}-\mathrm{AscH}^{-}$.

Our hypothesis for the selective toxicity of $\mathrm{P}-\mathrm{AscH}^{-}$to cancer cells and its relative harmlessness to non-malignant cells is centered on the altered redox metabolism of cancer cells. We have proposed that fundamental defects in cancer cell mitochondrial metabolism result in increased steady-state levels of reactive oxygen species, including $\mathrm{O}_{2}{ }^{\bullet-}$ and $\mathrm{H}_{2} \mathrm{O}_{2}$ (Figure 2) [5]. We further propose that redox-active, labile metals, specifically iron (Fe), are central to the toxicity of $\mathrm{P}-\mathrm{AscH}^{-}[39,43,57]$. This iron serves as a multiplier of oxidative damage from ROS by: (1) facilitating an increased flux of $\mathrm{H}_{2} \mathrm{O}_{2}$ by catalyzing the oxidation of ascorbate; and (2) "activating" this $\mathrm{H}_{2} \mathrm{O}_{2}$, via the Fenton reaction (vide infra), to form $\mathrm{HO}^{\bullet}$ that in turn oxidizes important biomolecules, such as DNA. 


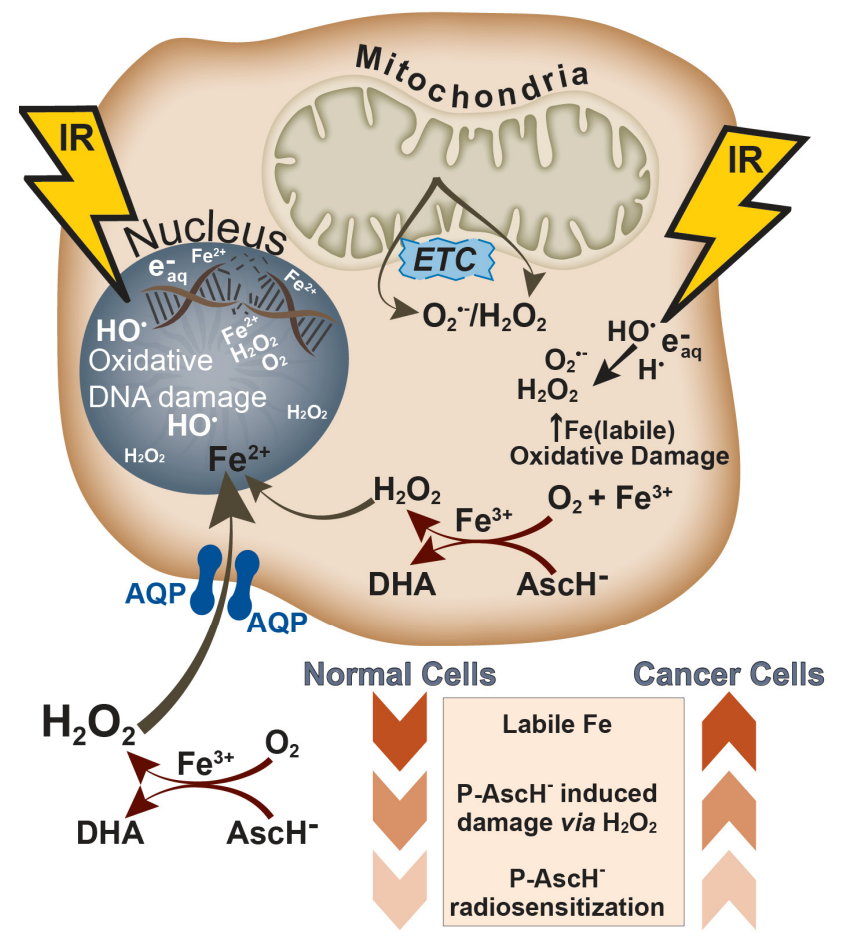

Figure 2. Proposed mechanism of action of $\mathrm{P}-\mathrm{AscH}^{-}$. With redox-active, labile iron as a catalyst, $\mathrm{P}-\mathrm{AscH}^{-}$generates high fluxes of $\mathrm{H}_{2} \mathrm{O}_{2}$, intracellularly and, especially, extracellularly. Extracellular $\mathrm{H}_{2} \mathrm{O}_{2}$ is readily brought into cells via aquaporins (AQP); some AQPs are referred to as peroxiporins as they efficiently take up, i.e., gate, $\mathrm{H}_{2} \mathrm{O}_{2}$. This pool of redox-active, labile iron also reacts with $\mathrm{H}_{2} \mathrm{O}_{2}$ producing the extremely oxidizing $\mathrm{HO}$. Because this pool of iron is mostly loosely coordinated to biomolecules, such as DNA, site-specific oxidative damage occurs. IR brings about complementary oxidative damage, via production of reactive species from the radiolysis of water, as well as direct damage to DNA, both double-strand and single-strand breaks. The DNA damage produced by $\mathrm{P}-\mathrm{AscH}^{-}$via $\mathrm{H}_{2} \mathrm{O}_{2}$ and redox-active, labile iron synergizes with intracellular $\mathrm{Fe}^{2+} / \mathrm{Fe}^{3+}$ to facilitate the propagation of oxidative events, leading to enhanced RT-induced DNA damage. IR, $\mathrm{O}_{2}{ }^{\cdot-}$, and $\mathrm{H}_{2} \mathrm{O}_{2}$ are each able to increase the level of labile iron, providing a feed-forward set of events. The ambient levels of labile iron and the steady-state levels of $\mathrm{H}_{2} \mathrm{O}_{2}$ and $\mathrm{O}_{2}{ }^{-}$are higher in cancer cells than in normal cells, leading to greater radiosensitization in the former than in normal cells. In fact, $\mathrm{P}-\mathrm{AscH}^{-}$appears to serve as a radio-protector to normal cells and tissues.

Below we present some of the chemical details showing how $\mathrm{P}-\mathrm{AscH}^{-}$leads to production of $\mathrm{H}_{2} \mathrm{O}_{2}$ and its interplay with intracellular Fe.

\section{Targeting Intracellular Iron to Enhance Radiation-induced Oxidative Damage}

\subsection{Disruption of Intracellular Iron Metabolism by $\mathrm{P}-\mathrm{AscH} \mathrm{H}^{-}$}

Cancer cells often accumulate Fe to levels above that of corresponding normal cells via increased iron import and decreased export [63-65]. This increased Fe content in tumors can turn P-AscH ${ }^{-}$into a pro-oxidant [59]. Chemically, ascorbate $\left(\mathrm{AscH}^{-}\right)$is an outstanding one-electron reductant. In appropriate coordination environments, $\mathrm{AscH}^{-}$can provide an electron to reduce $\mathrm{Fe}^{3+}$ to $\mathrm{Fe}^{2+}(\mathbf{R} \times \mathbf{n} 2)[59]$ :

$$
\mathrm{AscH}^{-}+\mathrm{Fe}^{3+} \rightarrow \mathrm{Asc}^{\bullet-}+\mathrm{Fe}^{2+}
$$

However, the enhanced flux of $\mathrm{H}_{2} \mathrm{O}_{2}$ produced by P-AscH ${ }^{-}$is also able to affect the distribution of intracellular iron [5]. $\mathrm{H}_{2} \mathrm{O}_{2}$ can interact with catalytically active $\mathrm{Fe}^{2+}$ via 
classic Fenton chemistry to generate hydroxyl radicals and further enhance detrimental oxidations ( $\mathbf{R x n} 3)$ [66]:

$$
\mathrm{Fe}^{2+}+\mathrm{H}_{2} \mathrm{O}_{2} \rightarrow \mathrm{Fe}^{3+}+\mathrm{HO}^{\bullet}+\mathrm{OH}^{-} \text {(Fenton reaction) }
$$

$\mathrm{Fe}^{2+}$ in near-neutral $\mathrm{pH}$ environments will react directly with oxygen, producing oxidants oxidants as well as superoxide ( $\operatorname{Rxn} 4)$ [67]:

$$
\mathrm{Fe}^{2+}+\mathrm{O}_{2} \rightarrow\left[\mathrm{Fe}^{2+}-\mathrm{O}_{2} \leftarrow \rightarrow \mathrm{Fe}^{3+}-\mathrm{O}_{2}^{\bullet-}\right] \rightarrow \mathrm{Fe}^{3+}+\mathrm{O}_{2}^{\bullet-}
$$

The loosely bound, redox-active $\mathrm{Fe}^{3+}$, often referred to as labile iron, can in principle be re-reduced by superoxide ( $\mathbf{R x n}$ ) [67]:

$$
\mathrm{Fe}^{3+}+\mathrm{O}_{2}^{\bullet-} \rightarrow \mathrm{Fe}^{2+}+\mathrm{O}_{2}
$$

However, Rxn 5 is an exceptionally rare event, with Rxn 2, as well as other cellular reduction processes, dominating. The more important reaction of superoxide, via its protonated form $\mathrm{HO}_{2}{ }^{\bullet}$, is the oxidation of enzymes containing [4Fe-4S] clusters that have a solvent-accessible iron, such as dehydratases. This results in the release of $\mathrm{Fe}^{2+}$ into the redox active, labile iron pool (Rxn 6) [68].

$$
\mathrm{HO}_{2} \bullet+[4 \mathrm{Fe}-4 \mathrm{~S}]^{2+}+\mathrm{H}^{+}{ }_{\mathrm{aq}} \rightarrow \mathrm{Fe}^{2+}+\mathrm{H}_{2} \mathrm{O}_{2}+[3 \mathrm{Fe}-4 \mathrm{~S}]^{1+}
$$

The released $\mathrm{Fe}^{2+}$ facilitates oxidative damage to cells, including DNA damage [69-71].

In addition to interacting with catalytically active $\mathrm{Fe}^{2+}$ via $\mathrm{Rxns} 2$ and $3, \mathrm{H}_{2} \mathrm{O}_{2}$ generated by $\mathrm{P}-\mathrm{AscH}^{-}$can oxidize these [4Fe-4S]-containing proteins, e.g., aconitase ( $\left.\mathbf{R x n} 7\right)[5,72,73]$.

$$
\mathrm{H}_{2} \mathrm{O}_{2}+[4 \mathrm{Fe}-4 \mathrm{~S}]^{2+} \rightarrow \mathrm{Fe}^{2+}+\mathrm{HO}^{\bullet}+\mathrm{OH}^{-}+[3 \mathrm{Fe}-4 \mathrm{~S}]^{1+}
$$

Similar to what is observed for superoxide, the $\mathrm{H}_{2} \mathrm{O}_{2}$-dependent oxidation of [4Fe$4 \mathrm{~S}]^{2+}$ is likely due to a chemical interaction with the solvent-exposed $\mathrm{Fe}^{2+}$ coordination site, leading to the release of a freely-chelatable $\mathrm{Fe}^{2+}[74,75]$. The rate constant for Rxn 7 is on the order of 1000 times smaller than $\mathrm{Rxn} 6$ at neutral $\mathrm{pH}$; however, the intracellular steady-state level of $\mathrm{H}_{2} \mathrm{O}_{2}$ is much greater than that of $\mathrm{O}_{2}{ }^{\bullet-} / \mathrm{HO}_{2} \bullet[76,77]$.

Aconitase is a TCA cycle intermediate that contains a $[4 \mathrm{Fe}-4 \mathrm{~S}]^{2+}$ cluster that is central to its enzymatic activity $[74,75]$. It has been previously shown in GBM and NSCLC cells that $\mathrm{P}-\mathrm{AscH}^{-}$can blunt aconitase activity [5]. This effect was ameliorated by catalase overexpression, consistent with the generation of $\mathrm{H}_{2} \mathrm{O}_{2}$ by $\mathrm{P}-\mathrm{AscH}^{-}$as a species that contributes significantly to the inactivation of aconitase.

The $\mathrm{Fe}^{2+}$ ion released can then be oxidized by $\mathrm{O}_{2}(\mathrm{Rxn} 4)$, which will contribute to the propagation of oxidation reactions [67]. Taken together, the interplay of $\mathrm{H}_{2} \mathrm{O}_{2}$ and $\mathrm{O}_{2}{ }^{\bullet-}$ with catalytically active, intracellular iron aids in the further propagation of oxidative damage initiated by $\mathrm{P}-\mathrm{AscH}^{-}$. These disruptions of Fe metabolism are proposed to be central to the selective radiosensitization of cancer cells by $\mathrm{P}_{-} \mathrm{AscH}^{-}$.

\subsection{Interactions of Iron and Ionizing Radiation}

Redox-active $\mathrm{Fe}^{2+/ 3+}$ can also be affected by IR; an increase in catalytically active $\mathrm{Fe}^{2+/ 3+}$ stimulated by $\mathrm{P}-\mathrm{AscH}^{-}$would further facilitate intracellular Fe radiochemistry. $\mathrm{Fe}^{2+}$ can be readily oxidized by the reactive chemical species produced by IR, as first described by Fricke and Morse in 1927 [78]. This reaction has since been adopted as a means to determine radiation dose in aqueous solutions. However, it may be applicable to cellular systems as well.

Immediately following dose deposition using low LET IR (e.g., photons), the radiolysis of $\mathrm{H}_{2} \mathrm{O}$ occurs, leading to the ionization of water ( $\left.\mathbf{R x n} 8\right)$ [33]:

$$
\mathrm{H}_{2} \mathrm{O}+\mathrm{IR} \rightarrow \mathrm{H}_{2} \mathrm{O}^{\bullet+}+\mathrm{e}_{\mathrm{aq}}{ }^{-}
$$


The aqueous electron can reduce $\mathrm{Fe}^{3+}$ and has been shown to lead to the reduction and release of Fe from ferritin, which results in an open Fe-binding site within the protein (Rxn 9):

$$
\mathrm{e}_{\mathrm{aq}}{ }^{-}+\mathrm{Fe}^{3+} \rightarrow \mathrm{Fe}^{2+}
$$

This reaction has been elucidated via pulse radiolysis but has not yet been fully examined in vitro.

The $\mathrm{H}_{2} \mathrm{O}^{\bullet+}$ of Rxn 8 will immediately deprotonate to yield the very oxidizing hydroxyl radical ( $\mathbf{x} \times \mathbf{1 0})$ :

$$
\mathrm{H}_{2} \mathrm{O}^{\bullet+} \rightarrow \mathrm{HO}^{\bullet}+\mathrm{H}^{+} \text {aq }
$$

The aqueous electron of $\mathrm{Rxn} 8$ will very rapidly react with $\mathrm{O}_{2}$, leading to the generation of superoxide ( $\mathbf{R x n} \mathbf{1 1})$ :

$$
\mathrm{e}_{\mathrm{aq}}{ }^{-}+\mathrm{O}_{2} \rightarrow \mathrm{O}_{2}^{\bullet-}
$$

Ionizing radiation can also simply result in homolytic bond cleavage (Rxn 12):

$$
\mathrm{H}_{2} \mathrm{O}+\mathrm{IR} \rightarrow \mathrm{HO}^{\bullet}+\mathrm{H}^{\bullet}
$$

Following the initial physiochemical steps associated with the hydrolysis of $\mathrm{H}_{2} \mathrm{O}, \mathrm{Fe}^{2+}$ can be readily oxidized by several chemical species. These chemical steps are typically used to estimate the radiation dose to water $\left(D_{w}\right)$ and are referred to as Fricke dosimetry $[78,79]$.

The hydrogen atom $\left(\mathrm{H}^{\bullet}\right)$ will also react with $\mathrm{O}_{2}$ to form a hydroperoxyl radical, i.e., protonated superoxide ( $\mathbf{x} x \mathbf{1 3})$, which can oxidize $\mathrm{Fe}^{2+}(\mathbf{R x n} \mathbf{1 4})$ :

$$
\begin{gathered}
\mathrm{H}^{+}{ }_{\text {aq }}+\mathrm{O}_{2} \rightarrow \mathrm{HO}_{2}{ }^{\bullet} \\
\mathrm{HO}_{2}^{\bullet}+\mathrm{Fe}^{2+}+\mathrm{H}^{+}{ }_{\text {aq }} \rightarrow \mathrm{Fe}^{3+}+\mathrm{H}_{2} \mathrm{O}_{2}
\end{gathered}
$$

$\mathrm{H}_{2} \mathrm{O}_{2}$ is now available for the Fenton reaction, $\mathrm{Rxn} 3$, to produce a hydroxyl radical. Lastly, each hydroxyl radical produced either via the Fenton reaction ( $\operatorname{Rxn} 3)$ or by the radiolysis of $\mathrm{H}_{2} \mathrm{O}$ can oxidize a $\mathrm{Fe}^{2+}(\mathbf{R x n} \mathbf{1 5})$ :

$$
\mathrm{HO}^{\bullet}+\mathrm{Fe}^{2+}+\rightarrow \mathrm{Fe}^{3+}+\mathrm{OH}^{-}
$$

Before considering the cellular effects of this chemical reaction, it is important to note the timescale on which these reactions occur [80]. There is a bi-phasic oxidation of $\mathrm{Fe}^{2+}$ in solution, with an initial burst of oxidation occurring in $\approx 10^{-8} \mathrm{~s}$ and maximizing at $\approx 10^{-6} \mathrm{~s}$. The first burst of $\mathrm{Fe}$ oxidation is the result of $\mathrm{HO}_{2}{ }^{\bullet}$-mediated oxidation ( $\left.\mathrm{Rxn} 14\right)$. There is a second burst of oxidation that begins at $\approx 10^{-4} \mathrm{~s}$ and reaches a maximum at $\approx 10^{-2} \mathrm{~s}$. The second burst of Fe oxidation is the result of $\mathrm{H}_{2} \mathrm{O}_{2}$ - and $\mathrm{HO}^{\bullet}$-mediated events; this $\mathrm{HO}^{\bullet}$ arises from the Fenton reaction, Rxn 3. Because these events occur so rapidly, Fricke dosimetry is a very useful tool for estimating the radiation dose. This chemistry illustrates the rich interplay between ROS produced by the radiolysis of water and iron, which will lead to the oxidation of cellular biomolecules (Figure 2).

While Fricke dosimetry has been used as a tool to accurately assess radiation dose, its application to biochemical models has yet to be extensively studied. In a chemical model, iron is able to bring about both single-stranded and double-stranded DNA breaks induced by $\gamma$-IR in a concentration-dependent manner, suggesting that the iron content may be a critical catalyst in IR-induced DNA damage [81]. Because of the timescale on which these reactions occur, the oxidation events catalyzed by iron are likely site-specific. That is, redox-active iron, principally as $\mathrm{Fe}^{2+}$, is loosely bound to target molecules such as DNA. This $\mathrm{Fe}^{2+}$ than reacts with $\mathrm{O}_{2}$ or $\mathrm{H}_{2} \mathrm{O}_{2}$ to form oxidants right at that location, bringing about oxidative damage, for example to DNA [56].

Other iron metabolic perturbations induced by IR have been evaluated in other biologically relevant models. Like $\mathrm{P}-\mathrm{AscH}^{-}$, IR has been shown in Chinese hamster fibroblast cells to bring about the oxidation of the $[4 \mathrm{Fe}-4 \mathrm{~S}]^{2+}$ cluster of aconitase [82]. 
In U373-MG cells, 5 Gy IR increased the expression of transferrin receptor 9-12 h after exposure [83]. This is consistent with the oxidation, and thus inactivation, of aconitase leading to the activation of iron response protein-1 (IRP1) [84,85]. This activation could further increase the iron content of cells and thereby increase the potential for more oxidative damage.

In addition to modifying Fe-S clusters, IR can also interact with heme. In red blood cells, a significant, dose-dependent increase in methemoglobin has been observed following $\gamma$-IR, indicating oxidation of the heme center [86]. It has also been observed that IR is able to increase the amount of redox-active Fe in MIA PaCa-2 pancreatic tumor homogenates. This report also showed an IR-dose-dependent increase in redox-active $\mathrm{Fe}^{2+/ 3+}$; the addition of $\mathrm{P}-\mathrm{AscH}^{-}$further enhanced this effect. More recently, IR has been shown to induce ferroptosis or Fe-catalyzed lipid peroxidation leading to cell death in various lung adenocarcinoma, NSCLC, and glioma cell lines $[87,88]$. Therefore, $\mathrm{P}-\mathrm{AscH}^{-}$-mediated iron metabolic perturbations are likely able to enhance radiosensitivity by increasing the redox-active pool of labile $\mathrm{Fe}^{2+/ 3+}$ following IR; this would further propagate damaging redox reactions, leading to enhanced site-specific damage to critical biomolecules, such as DNA.

\section{6. $\mathrm{P}-\mathrm{AscH}^{-}$as a Radioprotector in Normal Tissue}

As the data reviewed above indicate, $\mathrm{P}-\mathrm{AscH}^{-}$is a pro-oxidant in tumor cells via production of $\mathrm{H}_{2} \mathrm{O}_{2}$. However, it is neither cytotoxic towards normal tissue cells nor does it radiosensitize cells from normal tissues to IR (Figure 2). Moreover, there is mounting evidence that $\mathrm{P}-\mathrm{AscH}^{-}$may be radioprotective in cancer patients. Because $\mathrm{P}-\mathrm{AscH}^{-}$can act as an antioxidant in normal tissue, its reducing capacity may be a buffer to blunt the oxidative stress induced by chemoradiation in normal tissue [89,90]. The antioxidant effects of $\mathrm{P}-\mathrm{AscH}^{-}$have been purported to reduce chemoradiation side effects in clinical circumstances. In a study of breast cancer patients, treated weekly with chemoradiation or chemoradiation and $\mathrm{P}^{-\mathrm{AscH}^{-}}$(intravenous dosage of $7.5 \mathrm{~g}$ weekly), the subjects in the group treated with $\mathrm{P}-\mathrm{AscH}^{-}$indicated significantly fewer side effects than those in the group treated with only chemoradiation. However, because of limitations in the study, whether normal tissue protection or improved treatment efficacy was the driving factor for these improved quality-of-life indicators was not determined [91].

It is interesting that, in the phase I clinical trial with pancreatic cancer patients (vide supra), five of the patients in the $\mathrm{P}$ - $\mathrm{AscH}^{-}$-plus-gemcitabine group experienced decreased systemic oxidative stress, evaluated by plasma $\mathrm{F}_{2}$-isoprostane levels, compared to baseline oxidative stress [30]. In a previous pancreatic cancer in vivo study, researchers found that $\mathrm{P}-\mathrm{AscH}^{-}$did not increase systemic changes and oxidative stress markers [4]. Importantly, $\mathrm{P}-\mathrm{AscH}^{-}$appeared to partially reverse radiation-induced injury in jejunal crypts [5]. These studies provide both direct and indirect data consistent with $\mathrm{P}-\mathrm{AscH}^{-}$being a radioprotector for normal tissue.

These data on the potential radioprotection of normal tissue by $\mathrm{P}-\mathrm{AscH}^{-}$are promising. More detailed studies are clearly warranted, addressing basic mechanisms and especially clinical potential $[4,92,93]$.

\section{Conclusions}

From its first introduction in the 1970 s, $\mathrm{P}-\mathrm{AscH}^{-}$has had a controversial history as an anti-cancer drug. However, in the past two decades, there has been significant progress in understanding its safety, efficacy, and mechanism in inducing selective radiosensitization of cancer cells while protecting normal cells. $\mathrm{P}-\mathrm{AscH}^{-}$has been shown in vitro and in vivo to be an efficient radiosensitizer in various cancer types including glioblastoma, NSCLC, sarcoma, and pancreatic cancer, while preventing or reversing normal tissue injury by acting as an antioxidant in tissues and systemically [4,5,55,61]. Additionally, the data presented in this review show synergistically increased DNA damage with combination treatment of $\mathrm{RT}$ and $\mathrm{P}-\mathrm{AscH}^{-}$, associated with $\mathrm{H}_{2} \mathrm{O}_{2}$ formation. While there is ongoing research exploring the mechanism of $\mathrm{P}-\mathrm{AscH}^{-}$-induced toxicity in cancer cells as well as 
its role in normal tissue physiology, the current body of literature spanning preclinical and clinical research support continued exploration into this novel radio-sensitization strategy for several aggressive and prognostically concerning cancer types.

\section{Materials and Methods}

\subsection{Catalase Activity Assay}

Catalase activity was determined using UV-Vis spectroscopy by following the rate of removal (oxidation) of hydrogen peroxide due to catalase [94,95]. Hydrogen peroxide was monitored at $240 \mathrm{~nm}, \varepsilon_{240}=39.4 \mathrm{M}^{-1} \mathrm{~cm}^{-1}$ [96]. The assay was conducted in a $55.6 \mathrm{mM}$ ( $\mathrm{pH}$ 7.0) potassium phosphate buffer. The reaction was initiated by adding a $30 \mathrm{mM}$ $\mathrm{H}_{2} \mathrm{O}_{2}$ solution (in working buffer) to bring the final $\mathrm{H}_{2} \mathrm{O}_{2}$ concentration to $10 \mathrm{mM}$ in the cuvette. Immediately after adding $\mathrm{H}_{2} \mathrm{O}_{2}$, the kinetic analysis was started. The absorbance of hydrogen peroxide was monitored over $120 \mathrm{~s}$ at $10 \mathrm{~s}$ intervals. The rate of disappearance was then converted to a natural log to determine the $k U$ of activity. The protein content (Lowry protein assay) in each assay was determined and used to normalize the activity of catalase per $\mathrm{mg}$ of protein ( $\mathrm{mk} \mathrm{U} / \mathrm{mg}$ protein).

\subsection{Lentiviral Transduction of U87 Cells with Catalase}

The catalase-pTRIPZ vector was provided by the laboratory of Douglas Spitz [97]. To produce lentivirus, TSA201 cells were used along with VSV-G and psPAX2 helper vectors (Addgene, Watertown, MA, USA). The virus was collected from TSA201 cell cultures, centrifuged to remove cell debris, and filtered using $0.45 \mu \mathrm{m}$ filters from the ZymoPURE ${ }^{\mathrm{tm}}$ II Plasmid Midiprep Kit (Zymo Research, Irvine, CA, USA). U87 cells were plated and allowed to grow for $24 \mathrm{~h}$, and then virus was added to the cells with $8 \mu \mathrm{g} / \mathrm{mL}$ of polybrene for a total of $48 \mathrm{~h}$, with fresh virus being added after $24 \mathrm{~h}$. Following transduction, the cells were selected with $2.5 \mu \mathrm{g} / \mathrm{mL}$ puromycin. The general population that survived puromycin selection was then validated for overexpression of catalase by treatment with $1 \mu \mathrm{g} \mathrm{mL}^{-1}$ doxycycline hyclate (Fisher Bioreagents BP2653-5, Geel, Belgium) for $48 \mathrm{~h}$.

\section{3. $\gamma H 2 A X$ Staining and Flow Cytometry}

U87 GBM cells were cultured in BR-15 cell culture medium (DMEM F12, FBS, sodium pyruvate, Penicillin/streptomycin, HEPES, insulin, FGF) in T-175 flasks at $37{ }^{\circ} \mathrm{C}$ and $21 \%$ $\mathrm{O}_{2}$. Once cells reached a confluency of $70 \%$, the medium was removed, and the cells were harvested utilizing $0.25 \%$ trypsin-EDTA. Cells were counted using a Beckman Coulter Counter and then plated at $2.5 \times 10^{5}$ cells per plate in $60 \mathrm{~mm}$ dishes in BR-15. After $24 \mathrm{~h}$ at $37{ }^{\circ} \mathrm{C}$ and $21 \% \mathrm{O}_{2}$, the cells were treated with doxycycline (final concentration $1 \mu \mathrm{g} / \mathrm{mL}$ ). After $48 \mathrm{~h}$, the cells were divided in groups and subjected to different treatments. The P-AscH ${ }^{-}$treatment was $2 \mathrm{mM}$ (10 pmol/cell), and the RT dosage was $4 \mathrm{~Gy}$. For the combination of $\mathrm{P}_{-} \mathrm{AscH}^{-}$and $\mathrm{RT}, \mathrm{P}-\mathrm{AscH}^{-}$was administered for $1 \mathrm{~h}$ prior to RT. After RT, the cells were incubated for 30 to $45 \mathrm{~min}$, then were harvested utilizing $0.25 \%$ trypsinEDTA, and finally were washed with cold PBS. Following this, they were resuspended in cold $\left(-20^{\circ} \mathrm{C}\right) 70 \% \mathrm{EtOH}$ and incubated at $-20^{\circ} \mathrm{C}$ for $1 \mathrm{~h}$ before being placed at $4{ }^{\circ} \mathrm{C}$ for $48 \mathrm{~h}$ to fix them. After $48 \mathrm{~h}$, the fixed cells were washed with PBS and rehydrated in cold TBST. Then, a primary antibody for anti- $\gamma \mathrm{H} 2 \mathrm{AX}$ purchased from Cell signaling (Cat\#2577L) (rabbit polyclonal, 1:1000 diluted in TBST) was added to the fixed cells, which were incubated for $24 \mathrm{~h}$ at $4{ }^{\circ} \mathrm{C}$. The primary antibody was removed, and the cells were washed with PBS (2\% FBS) before applying the secondary antibody (FITC-conjugated goat anti-rabbit, purchased from Sigma Cat\#F0382, diluted 1:300 in TBST) for $1 \mathrm{~h}$ in the dark. The cells were then washed with PBS and resuspended in $500 \mu \mathrm{L}$ PBS for flow cytometry imaging. Mean Fluorescence Intensity (MFI) of 10,000 cells was collected, and autofluorescence was corrected for. Following data collection and analysis, paired $t$-tests were performed for statistical analysis. 
Author Contributions: B.G.A., D.R.S., M.S.P. and Z.M. conceptualized this review article. M.S.P. and K.A.M. assisted in organizing the article structure and sections. Z.M., M.S.P. and J.M.S. conducted the experiments presented in this article. A.L.K. conducted lentiviral transduction. Z.M. wrote Sections 1, 2, 6 and 8 as well as part of Sections 4 and 7. B.G.A. wrote Section 4. K.A.M. wrote Section 3. M.S.P. wrote Section 5. J.M.S. wrote Section 7 with Z.M., B.G.A., D.R.S. and J.M.B. supervised funding acquisition. J.M.B. edited the article. G.R.B. and J.J.C. edited and provided professional guidance for the manuscript. All authors have read and agreed to the published version of the manuscript.

Funding: This research was funded by NIH grants P01 CA217797, T32 CA078586, the Gateway for Cancer Research Grant G-17-1500, and the Carver College of Medicine.

Acknowledgments: Acknowledgements to the University of Iowa Department of Radiation Oncology, the Carver College of Medicine, and the Carver College of Medicine Summer Research Fellowship. The ESR Facility at the University of Iowa provided invaluable support. The content is solely the responsibility of the authors and does not represent views of the National Institutes of Health.

Conflicts of Interest: The authors declare no conflict of interest. The funders had no role in the design of the study; in the collection, analyses, or interpretation of data; in the writing of the manuscript, or in the decision to publish the results.

\section{References}

1. Manna, B.; Cooper, J.S. Radiation Therapy Induced Skin Ulcer. In StatPearls; StatPearls Publishing: Treasure Island, FL, USA, 2021.

2. Hanahan, D.; Weinberg, R.A. Hallmarks of cancer: The next generation. Cell 2011, 144, 646-674. [CrossRef]

3. Borek, C. Antioxidants and radiation therapy. J. Nutr. 2004, 134, 3207S-3209S. [CrossRef]

4. Du, J.; Cieslak, J.A., 3rd; Welsh, J.L.; Sibenaller, Z.A.; Allen, B.G.; Wagner, B.A.; Kalen, A.L.; Doskey, C.M.; Strother, R.K.; Button, A.M.; et al. Pharmacological Ascorbate Radiosensitizes Pancreatic Cancer. Cancer Res. 2015, 75, 3314-3326. [CrossRef]

5. Schoenfeld, J.D.; Sibenaller, Z.A.; Mapuskar, K.A.; Wagner, B.A.; Cramer-Morales, K.L.; Furqan, M.; Sandhu, S.; Carlisle, T.L.; Smith, M.C.; Abu Hejleh, T.; et al. $\mathrm{O}_{2}{ }^{--}$and $\mathrm{H}_{2} \mathrm{O}_{2}$-Mediated Disruption of Fe Metabolism Causes the Differential Susceptibility of NSCLC and GBM Cancer Cells to Pharmacological Ascorbate. Cancer Cell 2017, 32, 268. [CrossRef]

6. Chen, Q.; Espey, M.G.; Sun, A.Y.; Lee, J.H.; Krishna, M.C.; Shacter, E.; Choyke, P.L.; Pooput, C.; Kirk, K.L.; Buettner, G.R.; et al. Ascorbate in pharmacologic concentrations selectively generates ascorbate radical and hydrogen peroxide in extracellular fluid in vivo. Proc. Natl. Acad. Sci. USA 2007, 104, 8749-8754. [CrossRef]

7. Cameron, E.; Pauling, L. Ascorbic acid and the glycosaminoglycans. An orthomolecular approach to cancer and other diseases. Oncology 1973, 27, 181-192. [CrossRef]

8. Wen, P.Y.; Kesari, S. Malignant gliomas in adults. N. Engl. J. Med. 2008, 359, 492-507. [CrossRef] [PubMed]

9. Al-Dorzi, H.M.; Alruwaita, A.A.; Marae, B.O.; Alraddadi, B.S.; Tamim, H.M.; Ferayan, A.; Arabi, Y.M. Incidence, risk factors and outcomes of seizures occurring after craniotomy for primary brain tumor resection. Neurosciences 2017, 22, 107-113. [CrossRef] [PubMed]

10. Chang, C.H.; Horton, J.; Schoenfeld, D.; Salazer, O.; Perez-Tamayo, R.; Kramer, S.; Weinstein, A.; Nelson, J.S.; Tsukada, Y. Comparison of postoperative radiotherapy and combined postoperative radiotherapy and chemotherapy in the multidisciplinary management of malignant gliomas. A joint Radiation Therapy Oncology Group and Eastern Cooperative Oncology Group study. Cancer 1983, 52, 997-1007. [CrossRef]

11. Kong, D.S.; Lee, J.I.; Park, K.; Kim, J.H.; Lim, D.H.; Nam, D.H. Efficacy of stereotactic radiosurgery as a salvage treatment for recurrent malignant gliomas. Cancer 2008, 112, 2046-2051. [CrossRef] [PubMed]

12. Stupp, R.; Mason, W.P.; van den Bent, M.J.; Weller, M.; Fisher, B.; Taphoorn, M.J.; Belanger, K.; Brandes, A.A.; Marosi, C.; Bogdahn, U.; et al. Radiotherapy plus concomitant and adjuvant temozolomide for glioblastoma. N. Engl. J. Med. 2005, 352, 987-996. [CrossRef] [PubMed]

13. Lemjabbar-Alaoui, H.; Hassan, O.U.; Yang, Y.W.; Buchanan, P. Lung cancer: Biology and treatment options. Biochim. Biophys. Acta 2015, 1856, 189-210. [CrossRef] [PubMed]

14. Molina, J.R.; Yang, P.; Cassivi, S.D.; Schild, S.E.; Adjei, A.A. Non-small cell lung cancer: Epidemiology, risk factors, treatment, and survivorship. Mayo Clin. Proc. 2008, 83, 584-594. [CrossRef]

15. Alexander, M.S.; Wilkes, J.G.; Schroeder, S.R.; Buettner, G.R.; Wagner, B.A.; Du, J.; Gibson-Corley, K.; O’Leary, B.R.; Spitz, D.R.; Buatti, J.M.; et al. Pharmacologic Ascorbate Reduces Radiation-Induced Normal Tissue Toxicity and Enhances Tumor Radiosensitization in Pancreatic Cancer. Cancer Res. 2018, 78, 6838-6851. [CrossRef]

16. Iacobuzio-Donahue, C.A.; Fu, B.; Yachida, S.; Luo, M.; Abe, H.; Henderson, C.M.; Vilardell, F.; Wang, Z.; Keller, J.W.; Banerjee, P.; et al. DPC4 gene status of the primary carcinoma correlates with patterns of failure in patients with pancreatic cancer. J. Clin. Oncol. 2009, 27, 1806-1813. [CrossRef] 
17. Cameron, E.; Pauling, L. The orthomolecular treatment of cancer. I. The role of ascorbic acid in host resistance. Chem. Biol. Interact. 1974, 9, 273-283. [CrossRef]

18. Cameron, E.; Campbell, A. The orthomolecular treatment of cancer. II. Clinical trial of high-dose ascorbic acid supplements in advanced human cancer. Chem. Biol. Interact. 1974, 9, 285-315. [CrossRef]

19. Cameron, E.; Campbell, A.; Jack, T. The orthomolecular treatment of cancer. III. Reticulum cell sarcoma: Double complete regression induced by high-dose ascorbic acid therapy. Chem. Biol. Interact. 1975, 11, 387-393. [CrossRef]

20. Cameron, E.; Pauling, L. Supplemental ascorbate in the supportive treatment of cancer: Prolongation of survival times in terminal human cancer. Proc. Natl. Acad. Sci. USA 1976, 73, 3685-3689. [CrossRef]

21. Cameron, E.; Pauling, L. Supplemental ascorbate in the supportive treatment of cancer: Reevaluation of prolongation of survival times in terminal human cancer. Proc. Natl. Acad. Sci. USA 1978, 75, 4538-4542. [CrossRef]

22. Creagan, E.T.; Moertel, C.G.; O'Fallon, J.R.; Schutt, A.J.; O'Connell, M.J.; Rubin, J.; Frytak, S. Failure of high-dose vitamin C (ascorbic acid) therapy to benefit patients with advanced cancer. A controlled trial. N. Engl. J. Med. 1979, 301, 687-690. [CrossRef] [PubMed]

23. Wittes, R.E. Vitamin C and cancer. N. Engl. J. Med. 1985, 312, 178-179. [CrossRef] [PubMed]

24. Padayatty, S.J.; Sun, H.; Wang, Y.; Riordan, H.D.; Hewitt, S.M.; Katz, A.; Wesley, R.A.; Levine, M. Vitamin C pharmacokinetics: Implications for oral and intravenous use. Ann. Intern. Med. 2004, 140, 533-537. [CrossRef] [PubMed]

25. Graumlich, J.F.; Ludden, T.M.; Conry-Cantilena, C.; Cantilena, L.R., Jr.; Wang, Y.; Levine, M. Pharmacokinetic model of ascorbic acid in healthy male volunteers during depletion and repletion. Pharm. Res. 1997, 14, 1133-1139. [CrossRef] [PubMed]

26. Levine, M.; Padayatty, S.J.; Espey, M.G. Vitamin C: A concentration-function approach yields pharmacology and therapeutic discoveries. Adv. Nutr. 2011, 2, 78-88. [CrossRef] [PubMed]

27. Levine, M.; Conry-Cantilena, C.; Wang, Y.; Welch, R.W.; Washko, P.W.; Dhariwal, K.R.; Park, J.B.; Lazarev, A.; Graumlich, J.F.; King, J.; et al. Vitamin C pharmacokinetics in healthy volunteers: Evidence for a recommended dietary allowance. Proc. Natl. Acad. Sci. USA 1996, 93, 3704-3709. [CrossRef] [PubMed]

28. Riordan, H.D.; Riordan, N.H.; Jackson, J.A.; Casciari, J.J.; Hunninghake, R.; Gonzalez, M.J.; Mora, E.M.; Miranda-Massari, J.R.; Rosario, N.; Rivera, A. Intravenous vitamin C as a chemotherapy agent: A report on clinical cases. Health Sci. J. 2004, 23, 115-118.

29. Monti, D.A.; Mitchell, E.; Bazzan, A.J.; Littman, S.; Zabrecky, G.; Yeo, C.J.; Pillai, M.V.; Newberg, A.B.; Deshmukh, S.; Levine, M. Phase I evaluation of intravenous ascorbic acid in combination with gemcitabine and erlotinib in patients with metastatic pancreatic cancer. PLoS ONE 2012, 7, e29794. [CrossRef] [PubMed]

30. Welsh, J.L.; Wagner, B.A.; van't Erve, T.J.; Zehr, P.S.; Berg, D.J.; Halfdanarson, T.R.; Yee, N.S.; Bodeker, K.L.; Du, J.; Roberts, L.J., 2nd; et al. Pharmacological ascorbate with gemcitabine for the control of metastatic and node-positive pancreatic cancer (PACMAN): Results from a phase I clinical trial. Cancer Chemother. Pharmacol. 2013, 71, 765-775. [CrossRef]

31. Allen, B.G.; Bodeker, K.L.; Smith, M.C.; Monga, V.; Sandhu, S.; Hohl, R.; Carlisle, T.; Brown, H.; Hollenbeck, N.; Vollstedt, S.; et al. First-in-Human Phase I Clinical Trial of Pharmacologic Ascorbate Combined with Radiation and Temozolomide for Newly Diagnosed Glioblastoma. Clin. Cancer Res. 2019, 25, 6590-6597. [CrossRef]

32. Hegi, M.E.; Diserens, A.C.; Gorlia, T.; Hamou, M.F.; de Tribolet, N.; Weller, M.; Kros, J.M.; Hainfellner, J.A.; Mason, W.; Mariani, L.; et al. MGMT gene silencing and benefit from temozolomide in glioblastoma. N. Engl. J. Med. 2005, 352, 997-1003. [CrossRef]

33. Hall, E.J.; Giaccia, A.J. Radiobiology for the Radiologist, 8th ed.; Wolters Kluwer: Philadelphia, PA, USA, 2019; 597p.

34. Ohashi, Y.; Sakai, K.; Hase, H.; Joki, N. Dry weight targeting: The art and science of conventional hemodialysis. Semin. Dial. 2018, 31, 551-556. [CrossRef]

35. Spitz, D.R.; Azzam, E.I.; Li, J.J.; Gius, D. Metabolic oxidation/reduction reactions and cellular responses to ionizing radiation: A unifying concept in stress response biology. Cancer Metastasis Rev. 2004, 23, 311-322. [CrossRef]

36. Liou, G.Y.; Storz, P. Reactive oxygen species in cancer. Free Radic. Res. 2010, 44, 479-496. [CrossRef]

37. Szatrowski, T.P.; Nathan, C.F. Production of large amounts of hydrogen peroxide by human tumor cells. Cancer Res. 1991, 51, 794-798.

38. Aykin-Burns, N.; Ahmad, I.M.; Zhu, Y.; Oberley, L.W.; Spitz, D.R. Increased levels of superoxide and $\mathrm{H}_{2} \mathrm{O}_{2}$ mediate the differential susceptibility of cancer cells versus normal cells to glucose deprivation. Biochem. J. 2009, 418, 29-37. [CrossRef]

39. Oberley, L.W.; Buettner, G.R. Role of superoxide dismutase in cancer: A review. Cancer Res. 1979, 39, 1141-1149. [PubMed]

40. Ahmad, I.M.; Aykin-Burns, N.; Sim, J.E.; Walsh, S.A.; Higashikubo, R.; Buettner, G.R.; Venkataraman, S.; Mackey, M.A.; Flanagan, S.W.; Oberley, L.W.; et al. Mitochondrial $\mathrm{O}_{2}{ }^{*}$ - and $\mathrm{H}_{2} \mathrm{O}_{2}$ mediate glucose deprivation-induced stress in human cancer cells. J. Biol. Chem. 2005, 280, 4254-4263. [CrossRef] [PubMed]

41. Babior, B.M. NADPH oxidase: An update. Blood 1999, 93, 1464-1476. [CrossRef] [PubMed]

42. Storz, P. Reactive oxygen species in tumor progression. Front. Biosci. 2005, 10, 1881-1896. [CrossRef]

43. Afifi, A.K.; Jacoby, C.G.; Bell, W.E.; Menezes, A.H. Aqueductal stenosis and neurofibromatosis: A rare association. J. Child. Neurol. 1988, 3, 125-130. [CrossRef] [PubMed]

44. Buettner, G.R. Superoxide dismutase in redox biology: The roles of superoxide and hydrogen peroxide. Anticancer Agents Med. Chem. 2011, 11, 341-346. [CrossRef] [PubMed]

45. Chio, I.I.C.; Tuveson, D.A. ROS in Cancer: The Burning Question. Trends Mol. Med. 2017, 23, 411-429. [CrossRef] [PubMed]

46. Giuranno, L.; Ient, J.; De Ruysscher, D.; Vooijs, M.A. Radiation-Induced Lung Injury (RILI). Front. Oncol. 2019, 9, 877. [CrossRef] 
47. Brandes, A.A.; Tosoni, A.; Spagnolli, F.; Frezza, G.; Leonardi, M.; Calbucci, F.; Franceschi, E. Disease progression or pseudoprogression after concomitant radiochemotherapy treatment: Pitfalls in neurooncology. Neuro Oncol. 2008, 10, 361-367. [CrossRef] [PubMed]

48. Gondi, V.; Pugh, S.L.; Tome, W.A.; Caine, C.; Corn, B.; Kanner, A.; Rowley, H.; Kundapur, V.; DeNittis, A.; Greenspoon, J.N.; et al. Preservation of memory with conformal avoidance of the hippocampal neural stem-cell compartment during whole-brain radiotherapy for brain metastases (RTOG 0933): A phase II multi-institutional trial. J. Clin. Oncol. 2014, 32, 3810-3816. [CrossRef]

49. Turnquist, C.; Harris, B.T.; Harris, C.C. Radiation-induced brain injury: Current concepts and therapeutic strategies targeting neuroinflammation. Neurooncol. Adv. 2020, 2, vdaa057. [CrossRef] [PubMed]

50. Vigliani, M.C.; Duyckaerts, C.; Hauw, J.J.; Poisson, M.; Magdelenat, H.; Delattre, J.Y. Dementia following treatment of brain tumors with radiotherapy administered alone or in combination with nitrosourea-based chemotherapy: A clinical and pathological study. J. Neurooncol. 1999, 41, 137-149. [CrossRef]

51. Petronek, M.S.; Stolwijk, J.M.; Murray, S.D.; Steinbach, E.J.; Zakharia, Y.; Buettner, G.R.; Spitz, D.R.; Allen, B.G. Utilization of redox modulating small molecules that selectively act as pro-oxidants in cancer cells to open a therapeutic window for improving cancer therapy. Redox Biol. 2021, 42, 101864. [CrossRef]

52. Stone, J.R.; Yang, S. Hydrogen peroxide: A signaling messenger. Antioxid. Redox Signal. 2006, 8, 243-270. [CrossRef]

53. Corpe, C.P.; Lee, J.H.; Kwon, O.; Eck, P.; Narayanan, J.; Kirk, K.L.; Levine, M. 6-Bromo-6-deoxy-L-ascorbic acid: An ascorbate analog specific for $\mathrm{Na}+$-dependent vitamin $\mathrm{C}$ transporter but not glucose transporter pathways. J. Biol. Chem. 2005, 280, 5211-5220. [CrossRef] [PubMed]

54. Lennicke, C.; Rahn, J.; Lichtenfels, R.; Wessjohann, L.A.; Seliger, B. Hydrogen peroxide-Production, fate and role in redox signaling of tumor cells. Cell Commun. Signal. 2015, 13, 39. [CrossRef] [PubMed]

55. Alexander, M.S.; O’Leary, B.R.; Wilkes, J.G.; Gibson, A.R.; Wagner, B.A.; Du, J.; Sarsour, E.; Hwang, R.F.; Buettner, G.R.; Cullen, J.J. Enhanced Pharmacological Ascorbate Oxidation Radiosensitizes Pancreatic Cancer. Radiat. Res. 2019, 191, 43-51. [CrossRef]

56. Doskey, C.M.; Buranasudja, V.; Wagner, B.A.; Wilkes, J.G.; Du, J.; Cullen, J.J.; Buettner, G.R. Tumor cells have decreased ability to metabolize $\mathrm{H}_{2} \mathrm{O}_{2}$ : Implications for pharmacological ascorbate in cancer therapy. Redox Biol. 2016, 10, 274-284. [CrossRef]

57. Du, J.; Cullen, J.J.; Buettner, G.R. Ascorbic acid: Chemistry, biology and the treatment of cancer. Biochim. Biophys. Acta 2012, 1826, 443-457. [CrossRef]

58. Chen, Q.; Espey, M.G.; Krishna, M.C.; Mitchell, J.B.; Corpe, C.P.; Buettner, G.R.; Shacter, E.; Levine, M. Pharmacologic ascorbic acid concentrations selectively kill cancer cells: Action as a pro-drug to deliver hydrogen peroxide to tissues. Proc. Natl. Acad. Sci. USA 2005, 102, 13604-13609. [CrossRef]

59. Buettner, G.R.; Jurkiewicz, B.A. Catalytic metals, ascorbate and free radicals: Combinations to avoid. Radiat. Res. 1996, 145, 532-541. [CrossRef]

60. Erudaitius, D.; Huang, A.; Kazmi, S.; Buettner, G.R.; Rodgers, V.G. Peroxiporin Expression Is an Important Factor for Cancer Cell Susceptibility to Therapeutic $\mathrm{H}_{2} \mathrm{O}_{2}$ : Implications for Pharmacological Ascorbate Therapy. PLoS ONE 2017, 12, e0170442. [CrossRef]

61. Ma, Y.; Chapman, J.; Levine, M.; Polireddy, K.; Drisko, J.; Chen, Q. High-dose parenteral ascorbate enhanced chemosensitivity of ovarian cancer and reduced toxicity of chemotherapy. Sci. Transl. Med. 2014, 6, 222ra218. [CrossRef] [PubMed]

62. Yun, J.; Mullarky, E.; Lu, C.; Bosch, K.N.; Kavalier, A.; Rivera, K.; Roper, J.; Chio, I.I.C.; Giannopoulou, E.G.; Rago, C.; et al. Vitamin C selectively kills KRAS and BRAF mutant colorectal cancer cells by targeting GAPDH. Science 2015, 350, 1391-1396. [CrossRef]

63. Petronek, M.S.; Spitz, D.R.; Buettner, G.R.; Allen, B.G. Linking Cancer Metabolic Dysfunction and Genetic Instability through the Lens of Iron Metabolism. Cancers 2019, 11, 1077. [CrossRef] [PubMed]

64. Schonberg, D.L.; Miller, T.E.; Wu, Q.; Flavahan, W.A.; Das, N.K.; Hale, J.S.; Hubert, C.G.; Mack, S.C.; Jarrar, A.M.; Karl, R.T.; et al. Preferential Iron Trafficking Characterizes Glioblastoma Stem-like Cells. Cancer Cell 2015, 28, 441-455. [CrossRef] [PubMed]

65. Kong, Y.; Hu, L.; Lu, K.; Wang, Y.; Xie, Y.; Gao, L.; Yang, G.; Xie, B.; He, W.; Chen, G.; et al. Ferroportin downregulation promotes cell proliferation by modulating the Nrf2-miR-17-5p axis in multiple myeloma. Cell Death Dis. 2019, 10, 624. [CrossRef] [PubMed]

66. Wardman, P.; Candeias, L.P. Fenton chemistry: An introduction. Radiat. Res. 1996, 145, 523-531. [CrossRef] [PubMed]

67. Qian, S.Y.; Buettner, G.R. Iron and dioxygen chemistry is an important route to initiation of biological free radical oxidations: An electron paramagnetic resonance spin trapping study. Free Radic. Biol. Med. 1999, 26, 1447-1456. [CrossRef]

68. Keyer, K.; Imlay, J.A. Superoxide accelerates DNA damage by elevating free-iron levels. Proc. Natl. Acad. Sci. USA 1996, 93, 13635-13640. [CrossRef]

69. Keyer, K.; Gort, A.S.; Imlay, J.A. Superoxide and the production of oxidative DNA damage. J. Bacteriol. 1995, 177, 6782-6790. [CrossRef]

70. McCormick, M.L.; Buettner, G.R.; Britigan, B.E. Endogenous superoxide dismutase levels regulate iron-dependent hydroxyl radical formation in Escherichia coli exposed to hydrogen peroxide. J. Bacteriol. 1998, 180, 622-625. [CrossRef]

71. Vasquez-Vivar, J.; Kalyanaraman, B.; Kennedy, M.C. Mitochondrial aconitase is a source of hydroxyl radical. An electron spin resonance investigation. J. Biol. Chem. 2000, 275, 14064-14069. [CrossRef]

72. Gardner, P.R. Superoxide-driven aconitase FE-S center cycling. Biosci. Rep. 1997, 17, 33-42. [CrossRef]

73. Cantu, D.; Schaack, J.; Patel, M. Oxidative inactivation of mitochondrial aconitase results in iron and $\mathrm{H}_{2} \mathrm{O}_{2}$-mediated neurotoxicity in rat primary mesencephalic cultures. PLoS ONE 2009, 4, e7095. [CrossRef] [PubMed] 
74. Tong, W.H.; Rouault, T.A. Metabolic regulation of citrate and iron by aconitases: Role of iron-sulfur cluster biogenesis. Biometals 2007, 20, 549-564. [CrossRef] [PubMed]

75. Pandey, A.; Pain, J.; Ghosh, A.K.; Dancis, A.; Pain, D. Fe-S cluster biogenesis in isolated mammalian mitochondria: Coordinated use of persulfide sulfur and iron and requirements for GTP, NADH, and ATP. J. Biol. Chem. 2015, 290, 640-657. [CrossRef]

76. Boveris, A.; Cadenas, E. Cellular sources and steady-state levels of reactive oxygen species. In Oxygen, Gene Expression and Cellular Function; Clerch, L.B., Massaro, D.J., Eds.; Marcel Dekker, Inc.: New York, NY, USA, 1997; pp. 1-25.

77. Flint, D.H.; Tuminello, J.F.; Emptage, M.H. The inactivation of Fe-S cluster containing hydro-lyases by superoxide. J. Biol. Chem. 1993, 268, 22369-22376. [CrossRef]

78. Fricke, H.; Morse, S. The chemical action of roentgen rays on dilute ferrosulphate solutions as a measure of dose. Am. J. Roentgenol. Radium Ther. 1927, 18, 430-432.

79. Schreiner, L.J. Review of Fricke Gel Dosimeters. J. Phys. Conf. Ser. 2004, 3, 9-21. [CrossRef]

80. Zakaria, A.M.; Lertnaisat, P.; Islam, M.M.; Meesungnoen, J.; Katsumura, Y.; Jay-Gerin, J.-P. Yield of the Fricke dosimeter irradiated with the recoil $\alpha$ and $\mathrm{Li}$ ions of the $10 \mathrm{~B}(\mathrm{n}, \alpha) 7 \mathrm{Li}$ nuclear reaction: Effects of multiple ionization and temperature. Can. J. Chem. 2021, 99, 425-435. [CrossRef]

81. Ambroz, H.B.; Bradshaw, T.K.; Kemp, T.J.; Kornacka, E.M.; Przybytniak, G.K. Role of Iron Ions in Damage to DNA: Influence of Ionising Radiation, UV Light and $\mathrm{H}_{2} \mathrm{O}_{2}$. J. Photochem. Photobiol. A Chem. 2001, 142, 9-18. [CrossRef]

82. Azzam, E.I.; Jay-Gerin, J.P.; Pain, D. Ionizing radiation-induced metabolic oxidative stress and prolonged cell injury. Cancer Lett. 2012, 327, 48-60. [CrossRef]

83. Kim, K.U.; Xiao, J.; Ni, H.T.; Cho, K.H.; Spellman, S.R.; Low, W.C.; Hall, W.A. Changes in expression of transferrin, insulin-like growth factor 1, and interleukin 4 receptors after irradiation of cells of primary malignant brain tumor cell lines. Radiat. Res. 2003, 160, 224-231. [CrossRef]

84. Cairo, G.; Ronchi, R.; Recalcati, S.; Campanella, A.; Minotti, G. Nitric oxide and peroxynitrite activate the iron regulatory protein-1 of J774A.1 macrophages by direct disassembly of the Fe-S cluster of cytoplasmic aconitase. Biochemistry 2002, 41, 7435-7442. [CrossRef]

85. Pantopoulos, K.; Hentze, M.W. Activation of iron regulatory protein-1 by oxidative stress in vitro. Proc. Natl. Acad. Sci. USA 1998, 95, 10559-10563. [CrossRef]

86. Rafiei, J.; Yavari, K.; Moosavi-Movahedi, A.A. Preferential role of iron in heme degradation of hemoglobin upon gamma irradiation. Int. J. Biol. Macromol. 2017, 103, 1087-1095. [CrossRef]

87. Ye, L.F.; Chaudhary, K.R.; Zandkarimi, F.; Harken, A.D.; Kinslow, C.J.; Upadhyayula, P.S.; Dovas, A.; Higgins, D.M.; Tan, H.; Zhang, Y.; et al. Radiation-Induced Lipid Peroxidation Triggers Ferroptosis and Synergizes with Ferroptosis Inducers. ACS Chem. Biol. 2020, 15, 469-484. [CrossRef]

88. Lei, G.; Zhang, Y.; Koppula, P.; Liu, X.; Zhang, J.; Lin, S.H.; Ajani, J.A.; Xiao, Q.; Liao, Z.; Wang, H.; et al. The role of ferroptosis in ionizing radiation-induced cell death and tumor suppression. Cell Res. 2020, 30, 146-162. [CrossRef]

89. Schoenfeld, J.D.; Alexander, M.S.; Waldron, T.J.; Sibenaller, Z.A.; Spitz, D.R.; Buettner, G.R.; Allen, B.G.; Cullen, J.J. Pharmacological Ascorbate as a Means of Sensitizing Cancer Cells to Radio-Chemotherapy While Protecting Normal Tissue. Semin. Radiat. Oncol. 2019, 29, 25-32. [CrossRef]

90. Sarsour, E.H.; Kalen, A.L.; Xiao, Z.; Veenstra, T.D.; Chaudhuri, L.; Venkataraman, S.; Reigan, P.; Buettner, G.R.; Goswami, P.C. Manganese superoxide dismutase regulates a metabolic switch during the mammalian cell cycle. Cancer Res. 2012, 72, 3807-3816. [CrossRef]

91. Vollbracht, C.; Schneider, B.; Leendert, V.; Weiss, G.; Auerbach, L.; Beuth, J. Intravenous vitamin C administration improves quality of life in breast cancer patients during chemo-/radiotherapy and aftercare: Results of a retrospective, multicentre, epidemiological cohort study in Germany. In Vivo 2011, 25, 983-990.

92. Kanter, M.; Akpolat, M. Vitamin C protects against ionizing radiation damage to goblet cells of the ileum in rats. Acta Histochem. 2008, 110, 481-490. [CrossRef]

93. Ito, Y.; Kinoshita, M.; Yamamoto, T.; Sato, T.; Obara, T.; Saitoh, D.; Seki, S.; Takahashi, Y. A combination of pre- and post-exposure ascorbic acid rescues mice from radiation-induced lethal gastrointestinal damage. Int. J. Mol. Sci. 2013, 14, 19618-19635. [CrossRef]

94. Beers, R.F., Jr.; Sizer, I.W. A spectrophotometric method for measuring the breakdown of hydrogen peroxide by catalase. J. Biol. Chem. 1952, 195, 133-140. [CrossRef]

95. Aebi, H. Catalase in vitro. Methods Enzymol. 1984, 105, 121-126. [CrossRef]

96. Nelson, D.P.; Kiesow, L.A. Enthalpy of decomposition of hydrogen peroxide by catalase at $25^{\circ} \mathrm{C}$ (with molar extinction coefficients of $\mathrm{H}_{2} \mathrm{O}_{2}$ solutions in the UV). Anal. Biochem. 1972, 49, 474-478. [CrossRef]

97. Brandt, K.E.; Falls, K.C.; Schoenfeld, J.D.; Rodman, S.N.; Gu, Z.; Zhan, F.; Cullen, J.J.; Wagner, B.A.; Buettner, G.R.; Allen, B.G.; et al. Augmentation of intracellular iron using iron sucrose enhances the toxicity of pharmacological ascorbate in colon cancer cells. Redox Biol. 2018, 14, 82-87. [CrossRef] 